\title{
ANALISIS INTERPRETASI MUSIK JAMAN BAROK PADA PRELUDE FROM SUITE NO.1 FOR VIOLONCELLO SOLO KARYA J.S. BACH
}

\author{
Wildany Mafazatin Nailiyah \\ Program Studi Seni Musik Fakultas Bahasa dan Seni Universitas Negeri Surabaya \\ E-Mail: wildanysgallery@gmail.com
}

\begin{abstract}
Researchers analyzed Baroque music interpretation on Prelude from Suite No.1 for Violoncello because of most people especially mussician and music students do not know about the proper interpretation of Baroque music. The method used in this study is a qualitative research, method that does not use numbers as the data source. The object of research is the interpretation of this song with several theories that support the form of music, musical structure, rules for interpreting Baroque music, and musical concepts from the Baroque Era. The results of his research were obtained by observation, interviews, and documentation. The introduction of Suite No.1 for Violoncello Solo by J.S. Bach has dual form consisting of parts one and two. Analysis of interpretations is carried out through baroque interpretations of musical rules consisting of metrics, slurs, separate notes, not equal notes, and dynamics. With $C$ or $4 / 4$ metrics, Prelude is played with a faster tempo starting from adagio to allegro. Various slurs are obtained which ultimately influence the interpretation of this song which adds to the pedal point. Separate notes also appear a lot like the characteristics of the Baroque music. Not the same note and diamika also influence someone playing the song. Through the following aspects, a way to play the Preliminary song was produced with the correct interpretation of Baroque music.
\end{abstract}

Keywords: Baroque Music, Interpretation, Prelude.

\begin{abstract}
Abstrak: Peneliti menganalisis interpretasi musik Jaman Barok pada lagu Prelude from Suite No.1 for Violoncello dilatar belakangi oleh kurangnya pemahaman banyak orang terutama para pemain dan mahasiswa musik tentang bagaimana penginterpretasian musik Jaman Barok yang tepat. Metode yang digunakan dalam penelitian ini adalah metode penelitian kualitatif karena tidak menggunakan angka-angka sebagai sumber datanya. Objek penelitian difokuskan pada interpretasi dari lagu tersebut dengan menerapkan beberapa teori diantaranya bentuk musik, struktur musik, aturan-aturan interpretasi musik Jaman Barok, dan ekspresi musik dari Jaman Barok. Hasil penelitiannya diperoleh dengan cara observasi, wawancara, dan dokumentasi. Prelude from Suite No.1 for Violoncello Solo karya J.S. Bach ini memiliki bentuk dual yang terdiri dari bagian satu dan bagian dua. Analisis dari interpretasinya dianalisis melalui aturan-aturan interpretasi musik Jaman Barok yang terdiri dari metrik, slur, detached notes, unequal notes, dan dinamika. Dengan metrik C atau 4/4 maka Prelude dimainkan dengan tempo yang lambat mulai dari adagio hingga allegro. Terdapat slur yang beragam yang akhirnya memengaruhi interpretasi dari lagu ini yang menonjolkan pedal pointnya. Detached notes juga banyak muncul seperti ciri khas dari lagu Jaman Barok. Unequal notes dan diamika juga saling memengaruhi bagaimana seseorang memainkan lagu tersebut. Melalui beberapa aspek tersebut akhirnya dihasilkan bagaimana cara memainkan lagu Prelude dengan interpretasi musik Jaman Barok yang tepat.
\end{abstract}

Kata Kunci: Musik Jaman Barok, Interpretasi, Prelude.

\section{PENDAHULUAN}

Barok adalah sebuah istilah untuk menyebutkan gaya bangunan atau arsitektur pada abad ke-17 hingga 18. Istilah Barok itu sendiri baru muncul pada abad ke-18 dalam sebuah buku karangan Denis Diderot yang berjudul Encyclopédie. Istilah ini kemudian dipakai untuk menyebut periode kesenian Eropa abad ke-17 hingga 18, termasuk seni musiknya. Seni musik yang berkembang pada Jaman Barok merupakan suatu reaksi atas musik polifon pada Jaman Renaisans dan musik Barok sedikit banyak dikuasai dengan basso continuo. Musik Barok juga memiliki ciri khas dan karakter yang berbeda dengan jaman- jaman yang lain. Mulai dari cara bermain hingga bentuk dan akustik organologi dari instrumennya. Perkembangan Musik di jaman Barok juga lebih pesat dari jaman-jaman sebelum jaman tersebut, terbukti dengan lahirnya bentuk-bentuk musik baru seperti opera, oratorio, kantata, konserto, dan suita. Tidak hanya itu, dalam Jaman Barok jua semakin berkembang musik-musik vokal dan musik instrumental.

Pemahaman masyarakat terhadap musik Barok kebanyakan sangatlah kurang. Masyarakat hanya menyebut musik barat dari abad ke-4 hingga ke-19 sebagai musik Klasik. Padahal dalam musik barat dibagi menjadi beberapa jaman, mulai dari musik Jaman Pertengahan (375-1400), musik Jaman 
Renaisans (1400-1600), musik Jaman Barok (16001750), musik Jaman Klasik (1750-1820), musik Jaman Romantik (1800-1890), dan musik Jaman Modern (1900-sekarang). Perkembangan setiap jaman juga membuat fungsi dari musik ikut berkembang yang hanya sebatas musik gereja, bisa berkembang menjadi musik profan, dan lain sebagainya. Fungsi musik sebagai sarana hiburan maupun pendidikan, tidak terlepas dari peran seorang komposer maupun arranger dalam menyampaikan ide musikalnya (Karyawanto, 2018: 9). Jadi, fungsi musik pada setiap jaman juga dipengaruhi oleh komponis dan tujuan komponis dalam menciptakan karya tersebut. Kurangnya pemahaman masyarakat akan perbedaan musik dari berbagai jaman itulah yang membuat peneliti tertarik untuk mengenalkan interpretasi musik dari sebuah jaman yaitu musik Jaman Barok.

Gaya musik barok pertama kali muncul di Italia. Pada awalnya masyarakat memprotes kehadiran harmoni baru, dengan nada-nada disonan yang tidak menyiapkan akor-akor konsonan pada akor-akor sebelumnya, menurut kebiasaan tradisi lama. Mereka juga tidak senang akan progresiprogresi kromatik yang mengaburkan sistem modal berdasarkan delapan modus grejawi, dan susunan yang tidak stabil (McNeill, 2002: 172). Pemakaian basso continuo adalah salah satu ciri khas dari permainan Musik Barok. Basso continuo terlihat dalam opera-opera pertama dari Jacopo Peri, Emilio de' Cavalieri, dan Giulio Caccini. Selain musik vokal, musik tari adalah sumber kedua untuk perkembangan musik instrumental di Eropa.

Musik jaman Barok tidak lepas dari komponiskomponis dan karya-karya musik Barok itu sendiri. Mulai dari G. Gabrieli, C. Monteverdi, J.B. Lully, A. Scarlatti, J.S. Bach, dan masih banyak yang lain. Dari beberapa komponis tersebut, terdapat nama J.S. Bach. J.S. Bach dianggap sebagai komponis yang menandai berakhirnya musik jaman Barok karena musik jaman Barok berakhir di abad ke-18 dan J.S. Bach juga meninggal di abad ke-18. J.S. Bach lahir di Eisenach, Jerman, pada 1685 dan meninggal pada 1750. Setelah orangtuanya meninggal pada 1695 dia diasuh oleh kakaknya, Johann Christoph Bach lalu mulai diajarkan untuk bermain organ dan biola. Setelah keluar dari rumah kakanya pada umur 15 tahun, ia menjadi anggota pemain koor gereja
Michaliskirche di kota Luneburg. Kemudian mendapatkan pekerjaan pertamanya sebagai organis di gereja kota Arnstadt pada 1702. Seorang pangeran yang terkesan dengan permainan organnya membuatnya mendapatkan tugas baru di Weimar dan mendorong J.S. Bach untuk membuat lebih banyak komposisi dan kantata-kantata. Pada akhir hidupnya, ia mulai mengalami kebutaan dan pada saat itu masih sempat menggubah Die Kunst Der Fugue 13 (BWV 1080) dengan mengeja not yang ada di kepalanya kepada istrinya. Namun karya tersebut tak sempat terselesaikan. Semasa hidupnya, J.S. Bach menciptakan 1071 karya dikutip menurut Bach-Werke-Verzeichnis (BWV)/daftar karya bach (Prier, 2007: 66). Mulai dari Suita, Sonata, Partita, Overture, Kantata, Oratorio, Passio, dan masih banyak lagi. Salah satu karyanya yang paling terkenal adalah suita, yang kemudian banyak ditranskripkan ke alat musik lain seperti viola, gitar, marimba, hingga trombon.

Suita (dari bahasa Perancis: deretan) sudah terdapat di Perancis pada abad ke-16, dimana istilah ini pertama kali muncul. Dalam abad ke-17/18 istilah suita dipakai di Eropa Barat dalam arti yang tak tentu, umumnya dimaksudkan ialah deretan beberapa tarian. (Prier, 1996: 70). Awalnya suita hanya terdiri dari dua rangkaian yaitu PavaneGailard, atau Pavane-Saltarello. Kemudian pada akhir abad 16 ditambahkan satu tarian lagi yaitu Piva. Puncak perkembangannya terjadi pada abad ke-17 sampai pertengahan abad ke-18. Menjadi Allemande - Courante - Sarabande - Gigue. Disini Nampak pengaruh dari berbagai bangsa Eropa dan keinginan untuk mengikut sertakan berbagai gaya yang berlainan. Mulai dari gaya Jerman, Perancis, Spanyol, serta Inggris atau Skotlandia. Pada abad ke-18 di Perancis muncullah bagian-bagian baru dalam suita dengan nama Gavotte, Bourree, Menuett serta bagian bukan tarian seperti Prelude, Chaconne, Passacaile (Prier, 1996: 75). Prelude adalah bagian depan dari beberapa suita. Prelude juga memiliki arti pembukaan atau pendahuluan. Selama era barok pada, Prelude biasa disajikan sebagai sebuah pengenalan terhadap sebuah movements yang panjang dan kompleks. Prelude juga dapat menjadi sebuah lagu yang berdiri sendiri di era romantik. Biasanya Prelude memiliki sedikit variasi ritmik dan motif melodi yang diulang-ulang. 
Memainkan sebuah karya musik jaman Barok memiliki aturan-aturan

dalam menginterpretasikannya. Aturan yang dimaksud disini bukan berarti membatasi pemain dalam menginterpretasikan sebuah karya musik, melainkan ingin mempertahankan tradisi, memprekaya teknik dan pengalaman bermusik yang akhirnya dapat membentuk musikalitas seseorang. Kurangnya pengetahuan terhadap aturan-aturan interpretasi jaman barok oleh musisi-musisi di jaman modern juga menjadi alasan penulis dalam pemilihan materi ini. Analisis karya ilmiah ini dapat mengoptimalkan pemahaman tentang bagaimana menginterpretasikan sebuah karya musik jaman Barok sesuai dengan jamannya. Penulis mengambil komposisi dari J.S. Bach dari Suite pertama di bagian Prelude BWV 1007 karena karya musik jaman Barok tersebut termasuk karya yang populer dan familiar. Peneliti menggunakan versi dari G.Hulshov yang diterbitkan sebelumnya oleh Van Loghum Slaterus dan diterbitkan ulang oleh Bärenreiter-Verlag di Basel, sebuah rumah penerbitan musik klasik Jerman yang berbasis di Kassel. Sebelum meneliti interpretasinya, akan diteliti terlebih dahulu bentuk musik dari prelude ini.

Menurut Veilhan, (1979: ix) "For it essential to speak about rules. The word may seem didactic and suggestive of fixed precepts. But in fact, for the musical era known as the Baroque, what we are concerned with is the body of traditions, principles, affects, conventions, and inventions which make up good taste that in the long run remains the sole criterion for expressing a musical discourse that is at once both alive and sensitive."Artinya Veilhan menyatakan bahwa ketika seseorang berbicara soal aturan, hal tersebut memang terdengar kaku. Tetapi faktanya untuk musik jaman Barok, yang dimaksudkan adalah bukannya membatasi seseorang dalam menginterpretasi sebuah karya musik, namun ingin mempertahankan tradisi, prinsip, konvensi, dan invensi yang akhirnya nanti akan memberikan seseorang sebuah rasa yang baik dan berkualitas dalam jangka panjang saat mengekspresikan sebuah karya musik. Semakin hidup dan menyentuh. Hal tersebut sesuai pula dengan pernyataan Hermeren tentang bagaimana seharusnya menginterpretasikan sebuah karya musik. Karena kurangnya tanda-tanda dan ekspresi dalam karya musik tersebut, maka permainannya mengacu pada aturan-aturan dari musik Jaman Barok. Aturan-aturan interpretasi musik Jaman Barok Meliputi metrik yang memiliki karakternya sendiri mulai dari metrik 4/4 atau C hingga 9/16. Terdapat pula Articulatory Silence atau keheningan artikulasi yang berarti setiap not tidak ditahan sepanjang notasi yang tertulis di partitur. Areasi diantara not ini disebut dengan "keheningan artikulasi". Terdapat pula detached notes, adalah ketika membagi sebuah not menjadi dua bagian yang sama yang mana bagian pertama adalah bagian yang memunculkan suara sedangkan bagian kedua adalah gema atau sustain dari bagian pertama. Selain itu terdapat pula slur, unequal notes, rubato, dan hiasan/ornamen. Dalam penelitian ini juga mengacu pada penelitian terdahulu yang relevan untuk menjadi acuan dalam penelitian karena memiliki beberapa kesamaan dalam beberapa aspek seperti metode penelitian dansama-sama menganalisis atau mengkaji masalah interpretasi.

\section{METODE}

Penelitian ini menggunakan pendekatan penelitian kualitatif deskriptif karena variable penelitian merupakan objek yang tidak perlu menggunakan pengukuran dan proses statistik. Menurut Moeloeng (2001: 6), data penelitian kualitatif yang dikumpulkan adalah data yang berupa kata-kata, gambar, dan bukan merupakan angka-angka. Penelitian ini bertujuan untuk mendeskripsikan bentuk dan struktur lagu Prelude from Suite No.1 for Unaccompanied Solo Cello yang akhirnya nanti akan diteliti cara penginterpretasian musik jaman Baroknya. Data yang dianalisis adalah partitur lagu Prelude from Suite No.1 for Unaccompanied Solo Cello versi dari G.Hulshov yang diterbitkan sebelumnya oleh Van Loghum Slaterus dan diterbitkan ulang oleh Bärenreiter-Verlag di Basel, sebuah rumah penerbitan musik klasik Jerman yang berbasis di Kassel.

Data utama dalam penelitian ini adalah teks musik dari Prelude from Suite No.1 for Violoncello Solo karya J.S. Bach. Ditambah dengan beberapa data pendukung eksternal berupa video pertunjukan dari beberapa pemain cello, buku-buku, artikel, dan 
Wildany Mafazatin Nailiyah

ANALISIS INTERPRETASI MUSIK JAMAN BAROK PADA PRELUDE FROM SUITE NO.1 FOR VIOLONCELLO SOLO

KARYA J.S. BACH

wawancara dengan narasumber untuk kepentingan analisis dan identifikasi.

Teknik pengambilan data dari penelitian ini yaitu dengan metode observasi, wawancara, dan dokumentasi. Observasi dilakukan degan pengamatan langsung terhadap objek penelitian untuk mendapat data mengenai bentuk musik dari Prelude from Suite No.1 for Violoncello Solo karya J.S. Bach kemudian dianalisis bagaimana penginterpretasiannya dalam interpretasi musik jaman Barok. Wawancara ditujukan kepada pihak yang dianggap ahli dalam hal penginterpretasian musik Barok. Peneliti sendiri menunjuk Asep Hidayat, S.Sn, M.Sn sebagai ahli sekaligus informan. Dokumentasi disini berupa partitur dan video dari komposisi Prelude from Suite No.1 for Violoncello Solo karya J.S. Bach dan video dari beberapa cellist.

Dalam melakukan analisis data, peneliti menggunakan tiga komponen yaitu reduksi data (data reduction), penyajian data (data display), dan penyimpulan (conclusion drawing/verification). Data penelitian yang diperoleh diperoleh melalui teknik pengumpulan data memiliki bentuk yang beraneka ragam. Bisa berbentuk partitur, video, dan hasil wawancara. Peneliti perlu menyortir data-data yang dianggap pokok sehingga dapat lebih mudah dalam melakukan penelitian. Sesuai dengan rumusan masalah penelitian, peneliti menggunakan data penelitian pokok berupa partitur lagu beserta video-video rekaman pertunjukan Prelude from Suite No. 1 for Violoncello Solo karya J.S. Bach.

Setelah melakukan reduksi data, langkah selanjutnya yang dilakukan peneliti adalah menyajikannya. Dengan menyajikan data, maka memudahkan untuk memahami apa yang terjadi, merencanakan kerja selanjutnya berdasarkan apa yang telah didapat. Seperti yang dijelaskan oleh Miles dan Huberman, proses menyajikan data dilakukan dengan teks yang bersifat naratif (Sugiyono, 2005: 249). Teks tersebut memuat seluruh data yang berupa analisis aturan-aturan interpretasi jaman barok. Data yang sudah direduksi disajikan kemudian dilakukan pengkajian. Peneliti membagi berdasarkan pembagian terbesar dalam struktur musik yaitu periode sampai kepada pembagian frase dan motif. Langkah ini dilakukan agar sebuah teks musik menjadi jelas antara kalimat

satu dengan yang lain serta untuk mengetahui apa saja yang terdapat pada teks tersebut. Di dalam sebuah musik yang menggunakan lirik, musik instrumental, atau musik tanpa lirik syair juga memiliki kalimat-kalimat di dalamnya. Kemudian pemilahan motif bertujuan untuk melihat corak apa saja yang ada dalam partitur Prelude from Suite No. 1 for Violoncello Solo.

Langkah selanjutnya yang dilakukan peneliti setelah data tersaji secara sistematis dan terperinci adalah menarik kesimpulan dan verifikasi data tersebut. Peneliti mendeskripsikan hasil analisis agar mudah dipahami untuk kemudian disimpulkan. Kesimpulan penelitian yang diperoleh tadi kemudian dikaji dengan menggunakan teori yang ada. Proses yang dilakukan peneliti adalah dengan membandingkan antara hasil analisis dari Prelude from Suite No. 1 for Violoncello Solo karya J.S. Bach dengan teori aturan-aturan interpretasi musik jaman Barok.

\section{HASIL DAN PEMBAHASAN}

Pada Prelude from Suite No.1 for Violoncello Solo karya J.S. Bach dibagi menjadi dua bagian atau biasa disebut denga bentuk dual. Bentuk dual adalah bentuk lagu dua bagian yang mendapat suatu modifikasi dalam sebuah bentuk khusus untuk musik instrumental (terutama selama jaman barok). Pada bagian satu didominasi oleh arpegio-arpegio yang digesek pada tiga senar Kita bisa menemukan arpegio yang penuh pada birama 1-4 dan birama 1519.

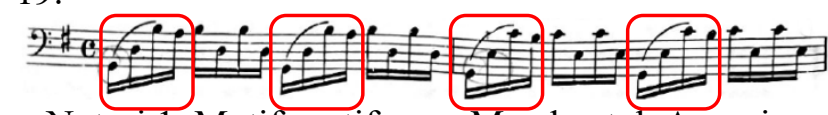

Notasi 1. Motif-motif yang Membentuk Arpegio

(Verlag, 1950: 4)

Pada bagian dua dimulai setelah tanda fermata pada birama 22 hingga birama 42 yang diakhiri dengan kadens $G$ mayor. Pada bagian dua ini arpegio-arpegio yang sering dijumpai pada bagian pertama mulai jarang ditemui. Meskipun muncul arpegio, arpegio tersebut hanya terdapat di awal lalu diikuti dengan tangga nada yang mewakili harmoni dari arpegio tersebut.

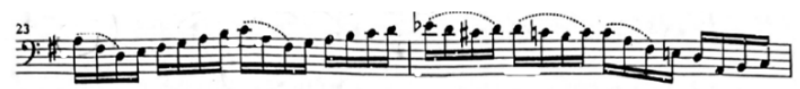

Notasi 2. Motif Nada yang Berurutan (Verlag, 1950: 5) 
Pada bagian prelude ini, di bar 1-5 terdapat tema utama (main theme) yang mengawali lagu prelude. Tema utama merupakan susunan berupa melodi atau akor yang sangat penting dalam sebuah karya. Biasanya motif atau kalimat utama yang akan dikembangkan pada birama-birama selanjutnya. Kebanyakan tema utama ini diletakkan di awal lagu/repertoar.

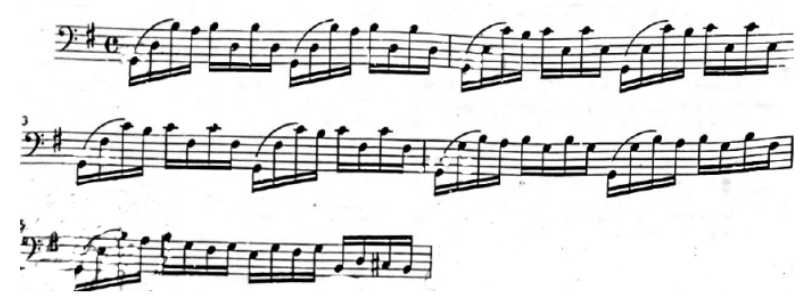

Notasi 3. Tema Utama

(Verlag, 1990: 4)

terdapat modulasi ke akor V (dominan) pada birama 6-13. Kemudian ada frase anteseden di birama 9 pada ketukan ketiga, yaitu sebagai kalimat tanya yang berupa melodi dengan progresi akor $\mathrm{V}$ ke akor I. Pada birama 9 terdapat authentic cadence yaitu progresi akor $\mathrm{V}$ ke akor I.

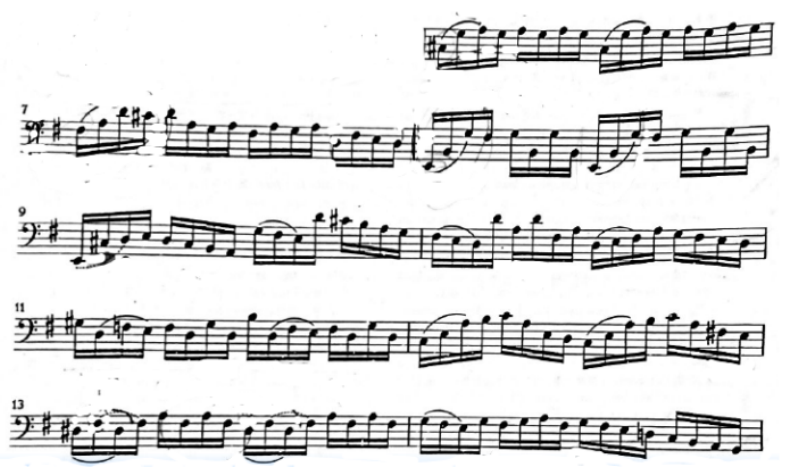

Notasi 4. Authentic Kadens

(Verlag, 1990: 4)

Pada biama 14, akornya kembali ke tonika atau nada dasar. Terdapat authentic cadence pada birama 18 yang ditandai dengan akor V. Pada birama 19 terdapat frase consequent yang merupakan kalimat jawab dari frase anteseden. Kemudian terdapat transisi di birama 20-22 pada ketukan kedua sebagai perpindahan ke bagian dua. Muncul tema baru di birama 22 ketukan ke tiga sebagai tema ke dua.

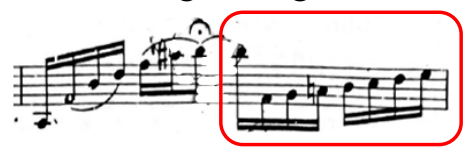

Notasi 5. Tema Baru di Bagian II
(Verlag, 1990: 5)

Terdapat codetta yaitu pengantar bagian penutup sebuah karya musik. Biasanya diletakkan sebelum coda. Dibutuhkan teknik bermain yaitu bow crossing dalam bagian codetta ini. Bow crossing yaitu detache bow dalam dua senar. Pada birama 31-38.

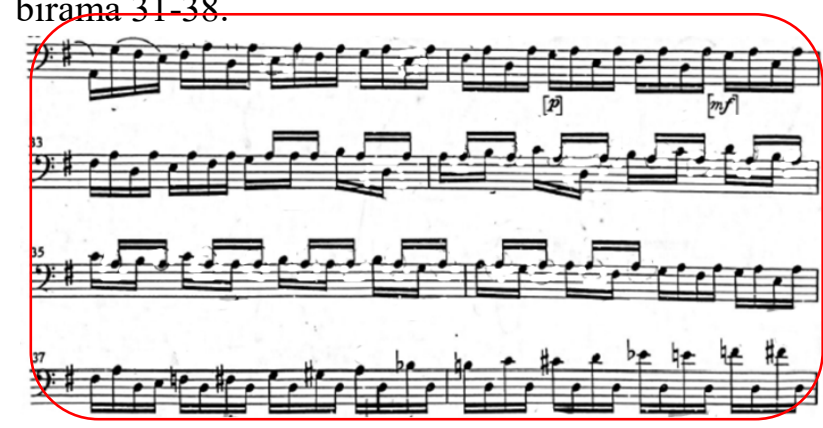

Notasi 6. Codetta

(Verlag, 1990: 5)

Pada bagian paling akhir sebagai penutup dalam sebuah karya musik, terdapat bagian yang disebut coda. Di dalam coda ini terdapat authentic cadence dan frase consequent sebagai kalimat jawab dari birama 30 .

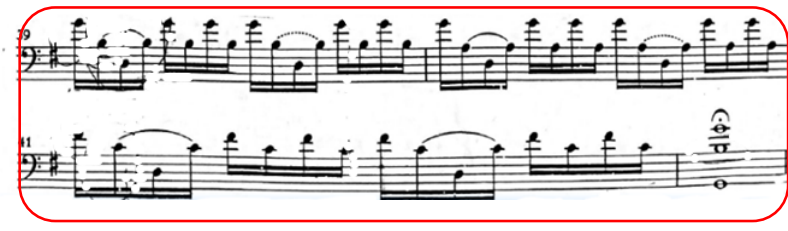

Notasi 7. Ending/coda

(Verlag, 1990: 5)

Pada karya musik Prelude from Suite No.1 for Violoncello Solo yang merupakan salah satu komposisi dari Jaman Barok dan ditulis oleh J.S Bach, memiliki beberapa aturan dalam penginterpretasiannya. Meskipun minim sekali dengan tanda-tanda dinamika, ornamen, dan lain sebagainya, memainkannya tidak sedatar seperti apa yang tertulis di teks musik. Banyak karya musik jaman barok tidak diatur secara tertulis baik ekspresi, dinamika, ornamen, bowing, dan lain sebagainya. Hanya dengan melihat sukat, bentuk musik, dan bagaimana motif juga nilai not, sebuah karya musik jaman Barok bisa dianalisis bagaimana cara penginterpretasiannya. Berikut adalah analisis interpretasi musik jaman Barok yang benar menurut beberapa teori.

Prelude from Suite No.1 for Violoncello Solo Karya J.S. Bach memiliki sukat $4 / 4$ atau biasa disebut common time. Sukat $\mathrm{C}$ dalam jaman barok 
biasanya memiliki tempo yang relatif pelan dan sering digunakan dalam instrumen vokal juga instrumen lain. Dalam lagu yang bersifat instrumental, sukat ini sangat cocok untuk dimainkan dalam Prelude, bagian pertama dari sebuah sonata, Allemande, fuga, dan beberapa bentuk musik yang lain.

Terdapat beberapa macam slur dalam aturanaturan interpretasi Jaman Barok. Dalam Prelude from Suite No.1 for Violoncello Solo Karya J.S. Bach. Yang pertama terdapat slur yang ditulis secara jelas.

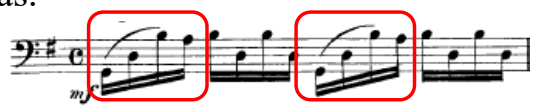

Notasi 8. Slur Pada Tiga Not Awal Motif

(Verlag, 1950: 4)

Pada birama 9 terdapat slur dengan garis putusputus. Slur ini memiliki arti slur yang disarankan oleh penulis di versi ini. Boleh digunakan dan boleh juga tidak.

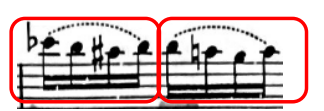

Notasi 9. Slur Bertitik pada Empat Not (Verlag, 1950: 5)

Pada birama 13 hingga birama 18 terdapat dua opsi slur. Ketika menggunakan slur yang atas maka pedal point akan dimainkan dengan durasi lebih lama dan menghasilkan gaung yang lebih besar. Ketika menggunakan slur yang bawah maka suara yang dihasilkan cenderung membentuk akor.

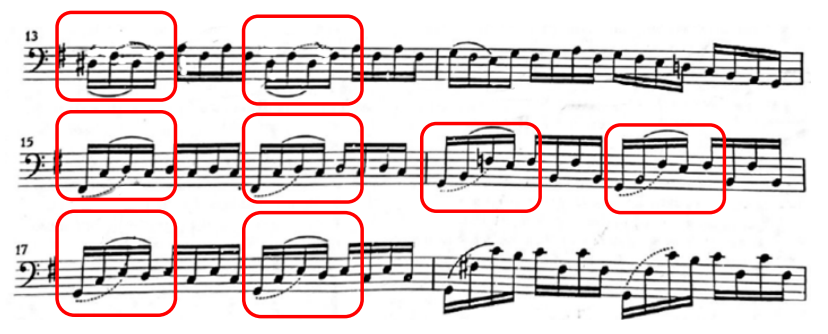

Notasi 10. Dua Opsi Slur

(Verlag, 1950: 4)

Pada birama 31 hingga birama 38 slur tidak dipergunakan sama sekali karena ingin menonjolkan antara pedal point dan garis melodinya.

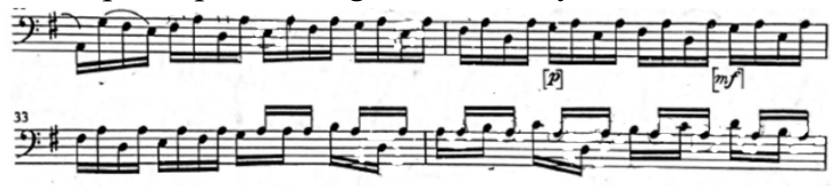

Notasi 11. Tidak Ada Slur

(Verlag, 1950: 5)
Tidak ada aturan yang spesial tentang tempo dari prelude. Prelude bisa dimainkan secara lembut, kasar, memanjang pendekkan not, dan banyak lagi, atau dalam kata lain selama bisa dimainkan dengan nyaman dan terdengar indah. Namun secara umum prelude memiliki tempo yang relatif pelan. Pada karya musik Prelude from Suite No.1 for Violoncello Solo Karya J.S. Bach cenderung menggunakan tempo 65 hingga $80 \mathrm{bpm}$. Artinya tempo yang sesuai adalah mulai dari adagio hingga andante. Tempo tersebut bisa memaksimalkan notnot seperenambelasan, arpegio-arpegio, dan banyak pedal point yang ada pada karya musik tersebut. Terbukti dengan beberapa cellist seperti Mystilav Rostropovich, Jacqueline Du-Pre, Yo-yo Ma, dan masih banyak lagi, menggunakan tempo antara adagio hingga andante dalam memainkan Prelude, meskipun tidak tertulis dalam teks musik.

Dalam karya ini terdapat banyak sekali pedal points, pedal points dimainkan secara detache agar menghasilkan sustain dan menjadi akar (root) dari nada-nada setelahnya.

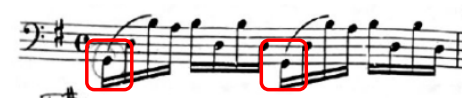

Notasi 12. Detached Notes pada Pedal Points

(Verlag, 1950: 4)

Selain detache dilakukan pada pedal points, detache juga dilakukan pada not not yang tidak dislur dan bukan rangkaian dari motif yang membentuk tangga nada.

Pada karya musik Prelude from Suite No.1 for Violoncello Solo Karya J.S. Bach, dari awal hingga akhir menggunakan not seperenambelasan. Hanya pada birama 22 saat berakhirnya bagian satu terdapat not $1 / 8$ yang di fermata. Kemudian pada bagian akhir terdapat kadens dengan nilai not empat ketuk. Seperti yang dikatakan Quantz, maka not-not seperenambelasan yang terdapat dalam karya ini tidak murni dimainkan sama dari awal hingga akhir. Namun, ada not not tertentu yang harus dipanjangkan atau dipendekkan.

Contohnya terdapat pada birama 1-8. Terdapat serangkaian nada seperenambelasan dan di dalamnya terdapat arpegio-arpegio. Arpegio dalam beberapa birama ini diawali dengan pedal point. Pedal point dimainkan dengan durasi yang lebih lama daripada nada-nada setelahnya meskipun dislur. Ini disebabkan karena pedal point berfungsi 
untuk mempertegas akor dalam satu bar. Unequal notes atau not yang tidak senilai dengan nilai not terdapat pada pedal point yang dimainkan lebih lama dan menimbulkan nilai notnya terdengar lebih besar dari pada not-not lainnya.

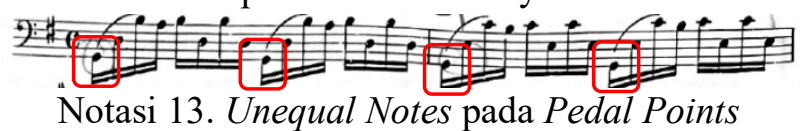
(Verlag, 1950: 4)

Pada birama sebelas, mulai beralih ke akor minor diawali dengan nada G\#. Nada G\# disini dimainkan lebih lama dan lebih diberi penekanan karena berfungsi sebagai awal dari akor minor. Selain nada G\# yang dimainkan tidak senilai, nada B3 pada ketukam ketiga ju\&a diberikan penekanan dan dimainkan lebih lama.

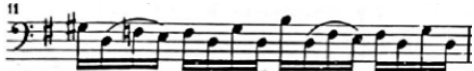

Notasi 14. Unequal Notes pada nada G\# dan B (Verlag, 1950: 4

Terdapat dua pilihan bowing yang ditulis oleh G.Hushlov, yang pertama terletak di tiga not dari awal setiap motif, dan yang kedua terletak di tiga not setelah nada pertama birama tiga belas. Perbedaan saat menggunakan bowing yang pertama dan yang kedua adalah pada durasi di pedal pointnya. Pedal point saat digunakan bowing pertama memiliki durasi yang lebih pendek daripada dengan bowing yang kedua, ini disebabkan karena bowing kedua pedal pointnya dimainkan dalam satu tarikan bow tanpa dislur dengan nada lainnya.

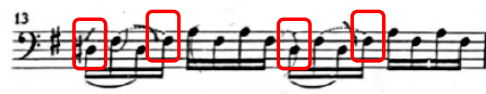

Notasi 15. Unequal Notes pada Dua Opsi Slur (Verlag, 1950: 4)

Birama 14 dimainkan secara mengalir karena tidak ada pedal point dan melodinya berupa tangga nada tanpa ada melodi yang menonjol. Tapi disini pada bagian terakhir tepatnya di ketukan keempat, saat melodi mulai turun ke senar $\mathrm{G}$, secara otomatis temponya akan semakin menurun dan nada nada terakhirnya mengalami ketidaksenilaian not. Hal ini terjadi karena nada C3, B2, A2, dan G2 adalah jembatan menuju motif yang sama seperti motif di awal.

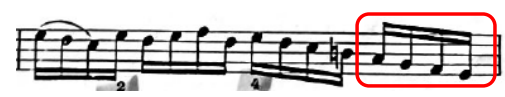

Notasi 16. Unequal Notes Saat Menuju Motif Awal (Verlag, 1950: 4)
Birama 15-18 memiliki motif yang sama seperti birama 1-8 dengan pedal point yang dimainkan dengan tidak senilai. Pada birama 19, terdapat arpegio diawal dan diikuti dengan tangga nada yang menurun dari B3 ke D2. Pedal point dimainkan lebih lama dan tangga nada setelah pedal point dimainkan dengan mengalir.

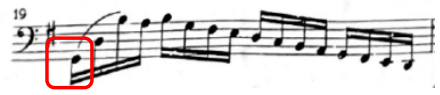

Notasi 17. Unequal Notes pada Pedal Points (Verlag, 1950: 4)

Birama 20-21 juga memiliki motif yang sama, yaitu motif yang diawali dengan arpegio dan diulang sama persis. Unequal notes nya pun masih sama yaitu di bagian peda point. Kemudian pada birama 22 terdapat arpegio dari C2 hingga D4 yang membentuk akor A mayor dengan pedal point pada C2 yang tidak dislur dengan akor lain yang akhirnya akan membuat nilai notnya lebih besar. Setelah tanda fermata terdapar rangkaian nada yang dimainkan secara mengalir hingga birama 23.

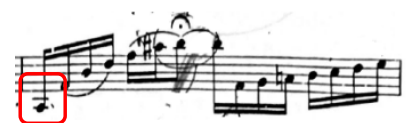

Notasi 88. Unequal Notes pada Nada C2

(Verlag, 1950: 5)

Pada birama 24, not naik setengah dari D4 pada birama sebelumnya menuju Eb4. Disinilah unequal notes digunakan. Nada Eb akan diberi penekanan dan durasi yang lebih lama juga nada D pada ketukan kedua dan nada $\mathrm{C}$ pada ketukan ketiga. Ini dilakukan karena terjadi pengulangan nada saat pergantian ketukan.

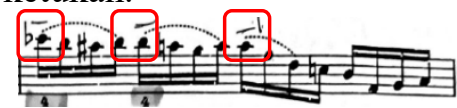

Notasi 19. Unequal Notes pada Nada yang Diulang (Verlag, 1950: 5)

Birama 25 memiliki unequal notes yang sama dengan birama 20-21 dengan pedal point pada arpegio dan diikuti dengan garis melodi. Demikian pula pada birama 26-28. Pada birama 29 terdapat satu rangkaian tangga nada yang diawali dengan pedal point. Masih sama, pedal point harus dimainkan lebih panjang daripada not-not setelahnya.

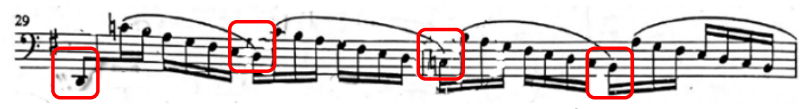

Notasi 20. Unequal Notes pada Pedal Points (Verlag, 1950: 5) 
Pada birama 30-33 memiliki motif dimana terdapat garis melodi dan pedal point yang dimainkan secara bergantian. Dalam hal ini bisa dimainkan secara rata dari awal hingga akhir. Pada birama 34 masih memiliki motif yang sama, tapi dengan diberi unequal notes pada nada B3, C3, dan D4. Hal ini karena nada-nada tersebut dimainkan pada senar D dengan posisi empat sehingga butuh penekanan-penekanan dan nada yang semakin naik.

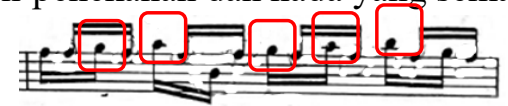

Notasi 21. Unequal Notes pada Nada B3, C3, dan D4

(Verlag, 1950: 5)

Kemudian pada birama 37-38 melodi semakin naik dengan nada-nada kromatik. Pada nada-nada kromatik, semakin tinggi nadanya maka nilai notnya akan semakin membesar karena nada-nada kromatik tersebut adalah penghantar menuju klimaks dari karya musik ini.

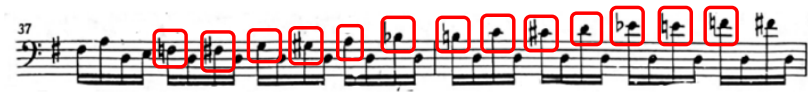

Notasi 22. Unequal Notes pada Nada Kromatik (Verlag, 1950: 5)

Pada birama 39-41 adalah bagian codetta juga klimaks dengan motif yang sama dengan tema awal namun dengan susunan yang dibalik dan bowingnya juga dibalik. Setiap not dari awal motif diberi durasi yang lebih lama dari pada not-not setelahnya sehinggabisa menghasilkan kesan bahwa lagu akan selesai. Kemudian ditutup dengan akor $\mathrm{G}$ mayor dibagian ending.

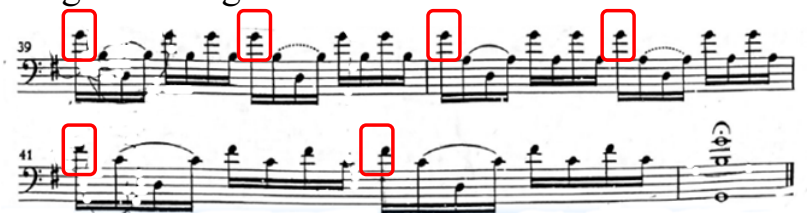

Notasi 23. Unequal Notes pada Codetta

(Verlag, 1950: 5)

Dalam interpretasi musik jaman Barok, memiliki dinamika yang lebih kompleks karena kebanyakan tidak ditulis dalam teks musik. Pemain harus mengartikan sendiri bagaimana dinamika pada sebuah motif, kalimat, frase, dan banyak lagi. Pada birama 1-4 terdapat motif yang membentuk arpegioarpegio dengan tiga not yang dislur pada bagian awal motif. Pada awal arpegio di birama satu, not yang di slur dimainkan lebih forte dari not berikutnya. Hal ini karena bagian tersebut mempertegas akor yang ada dengan pedal point di nada $\mathrm{G}$ yang lebih forte dari nada-nada yang lain. Terdapat motif ulangan harafiah atau motif yang diulang persis dengan nada yang sama di birama satu. Motif awal dimainkan lebih forte dari motif pengulangannya. Hal ini karena musik Jaman Barok memiliki ciri khas bahwa ketika ada motif yang diulang sama persis maka motif berikutnya dimainkan lebih lembut dari motif sebelumnya.

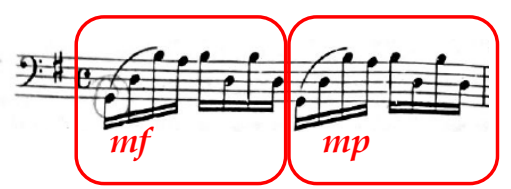

Notasi 24. Dinamika pada Motif Ulangan Harafiah (Verlag, 1950: 4)

Pada birama 4, masih menggunakan motif yang sama seperti birama sebelumnya, namun tidak diulang secara persis seperti motif pertamanya dalam satu bar. Pada nada terakhir di birama4 tidak menggunakan nada $G$ melainkan nada F\#. Nada F\# tersebut menunjukkan bahwa tema awal sudah selesai dan digunakan sebagai perantara menuju tema berikutnya. Jadi cara penginterpretasiannya masih sama seperti pada birama satu sampai birama tiga, namun disini yang membedakan saat tangan menekan nada F\# maka nada tersebut harus digesek lebih berat dan sedikit lebih lama.

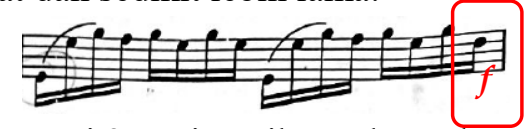

Notasi 25. Dinamika pada Nada F\#

(Verlag, 1950: 4)

Pada birama lima mulai muncul motif baru. Masih diawali dengan arpegio dengan not-not yang di-slur namun kali ini dengan nada-nada yang berbeda di setiap motifnya. Nada-nada yang tersusun pada birama lima menunjukkan akor Em dan merupakan jembatan untuk menuju akor VI atau submedian dari G. Rangkaian nada tersebut dimainkan satu persatu tanpa dislur. Pada ketukan satu sampai tiga masih dimainkan secara ringan kemudian intensitasnya meningkat atau semakin keras pada ketukan ke empat. Hal ini karena nadanada sudah dimainkan di senar tiga sehingga terkesan lebih berat, selain fungsinya untuk menuju akor VI nya. 


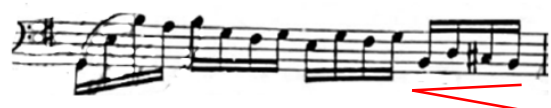

Notasi 26. Dinamika Menuju Akor VI

(Verlag, 1950: 4)

Pada birama enam, motif sama seperti pada birama satu hingga empat namun pada akor A7. Jadi penginterpretasiannya sama seperti birama satu sampai empat. Pada birama tujuh memiliki motif yang sama seperti birama lima namun dengan nada yang lebih tinggi dan nada-nadanya mewakili akor $\mathrm{D}$ atau dominan dari akor $\mathrm{G}$.

Pada birama delapan, memiliki motif yang sama seperti birama satu sampai birama empat dan birama enam, namun pada akor E minor. Terjadi dinamika yang berbeda dalam biramaini meskipun motifnya sama seperti birama sebelumnya. Hal ini dikarenakan pedal point pada biramadelapan tidak pada posisi senar yang terbuka. Pedal point dimainkan pada nada E2 yang terletak pada senar empat atau C2. Karena tidak pada posisi senar yang terbuka maka penekana pada nada E2 lebih besar dan membutuhkan durasi yang lebih lama daripada motif-motif sebelumnya yang sama persis. Dan secara otomatis akan menghasilkan dinamika yang lebih keras.

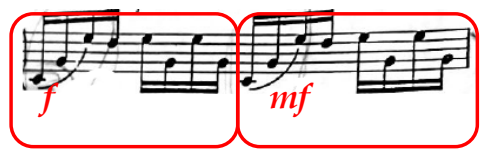

Notasi 27. Dinamika pada Interval Jauh (Verlag, 1950: 4)

Birama sembilan dan sepuluh arpegio mulai menghilang dan diganti dengan nada-nada berurutan seperti membentuk tangga nada. Pada birama sembilan diawali dengan arpegio yang membentuk akor A7, kemudian diikuti dengan garis melodi yang masih dalam akor A7. Pada birama ini, dimainkan secara mengalir karena pedal point pada bagian depan diikuti garis melodi hingga birama 10 . Dinamikanya semakin naik saat garis melodi naik, dan dinamikanya juga semakin lembut saat garis melodi semakin menurun.

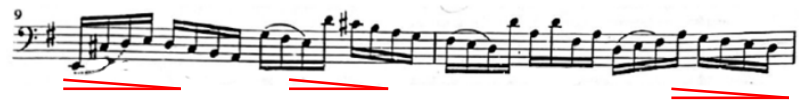

Notasi 28. Dinamika yang Mengikuti Garis Melodi (Verlag, 1950: 4)
Pada birama 11, dinamika akan naik pada notnot yang diberi penekanan. Contohnya pada nada G\# di ketukan pertama dan nada B di ketukan ketiga. Penekanan tersebut akan menimbulkan dinamika yang lebih keras dari pada not-not lainnya dalam birama tersebut.

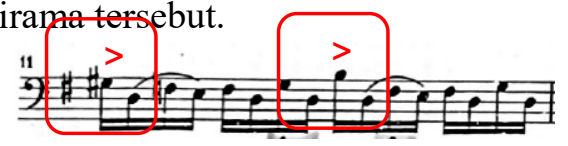

Notasi 29. Aksen pada Nada G\# dan B (Verlag, 1950: 4)

Pada birama 12 terdapat arpegio yang naik kemudian diikuti dengan rangkaian melodi yang turun pada setiap motif. Begitu pula dinamikanya, akan ikut naik turun seirama dengan nada yang naik juga turun.

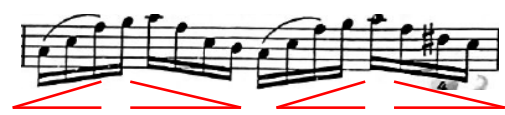

Notasi 30. Dinamika yang Mengikuti Garis Melodi (Verlag, 1950: 4)

Pada birama tiga belas dinamika tidak naik turun seperti birama sebelumnya dan lebih stabil. Pada birama empat belas terjadi crescendo pada akhir biramatepatnya pada ketukan ke empat. Hal tersebut karena pada empat nada tersebut adalah nada yang ditujukan untuk menuju tema berikutnya, jadi harus dipertegas dengan dinamika yang makin naik.

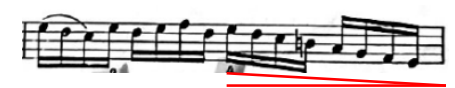

Notasi 31. Dinamika pada Garis Melodi Turun (Verlag, 1950: 4)

Pada birama 15-17, memiliki motif yang sama dengan birama 1-4 dan cara memainkannya pun sama yaitu dengan lebih menaikkan volume suara di motif pertama daripada pengulangannya. Kemudian pada birama 18 terdapat motif yang sama namun pada birama kali ini cenderung dimainkan lebih keras dari tiga birama sebelumnya karena terdapat interval nada yang jauh dan dimainkan di senar tiga hingga senar satu yang cenderung lebih nyaring.

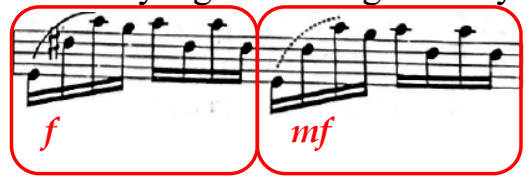

Notasi 32. Dinamika pada Interval yang Jauh (Verlag, 1950: 4) 
Dinamika semakin turun pada birama sembilan belas karena terdapat rangkaian tangga nada yang semakin turun dimulai dari nada B3 hingga D2. Kemudian berangsur naik sedikit-demi sedikit dari birama dua puluh, dan naik lagi di birama dua puluh satu, kemudian puncaknya ada di nada D pada birama 22 yang di fermata. Puncak dari dinamika tersebut mengakhiri bagian satu dari Prelude from Suite No. 1 for Violoncello Solo Karya J.S. Bach.

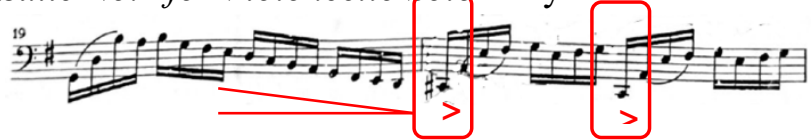

Notasi 33. Dinamika mengikuti Garis Melodi (Verlag, 1950: 4)

Bagian dua diawali dengan nada-nada berderet naik pada birama 22 yang diawali dengan dinamika yang lembut dan mengalami crescendo hingga nada G3. Kemudian pada birama 23, terdapat not yang dislur di awal motif dengan gerakan menurun. Pada tiga nada tersebut mengalami decrressendo yang kecil kemudian naik lagi ketika nada nya naik. Begitu pula berikutnya. Dan pada birama 24 terdapat penekanan penekanan pada ketukan awal dari nada-nada yang diulang. Hal tersebut berfungsi untuk mempertegas kedua nada tersebut dan dinamikanya kembali turun pada dua ketukan terakhir.

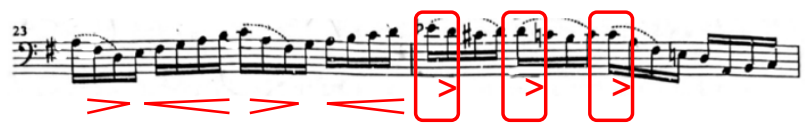

Notasi 34. Dinamika pada Not yang Diulang

(Verlag, 1950: 4)

Pada birama 25, terdapat pedal point yang digesek terpisah dan tidak di slur, berbeda seperti pada slur di motif awal. Ini menimbulkan dinamika yang lebih keras dan terdengar sedikit diberi tekanan dari not yang lain. Pada awal birama25 juga memiliki pola dan bowing yang sama. Kemudian di akhir birama 25 terdapat pola yang sama seperti birama 24 dimana terdapat pengulangan motif yang membuat setiap nada yang sama di ketukan pertama dimainkan lebih forte.

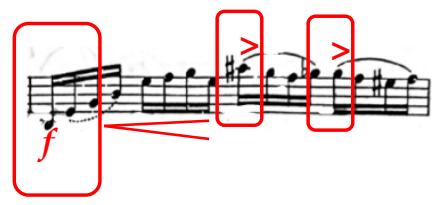

Notasi 35. Dinamika pada Pedal Points dan Pengulangan Motif (Verlag, 1950: 5)

Pada birama 26 diawali motif yang sama seperti birama 25, namun pada motif kedua mirip dengan birama 24 . Jadi setelah pedal point dimainkan lebih forte, kemudian lembut kembali pada not kedua dan makin naik hingga ke ketukan ketiga. Pada motif berikutnya, ada penekanan pada nada $\mathrm{CH}$ dan $\mathrm{Bb}$ sehingga dinamikanya lebih keras pada saat memainkan dua nada tersebut.

Pada birama 27 dan 28 memiliki garis melodi yang naik turun. Dinamikanya pun mengikuti garis melodi yang ada. Bisa semakin crescendo dan bisa juga semakin decrescendo. Pada birama 28 diakhiri dengan decrescendo hingga awal birama 29.

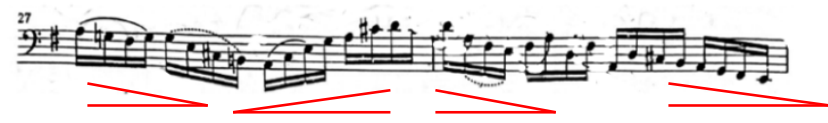

Notasi 36. Dinamika pada Garis Melodi yang Naik Turun

(Verlag, 1950: 5)

Pada birama 29 dan 30 terdapat garis melodi dengan motif yang menurun dan berulang. Pada nada paling tinggi secara otomatis dimainkan lebih forte dan pada saat menurun, dinamikanya semakin lembut. Saat motif tersebut diulang kembali, dinamikanya kembali naik dan semakin turun. Jadi terjadi pengulangan dinamika pada setiap motif dan semakin menurun sesuai denga tingkatan notnya.

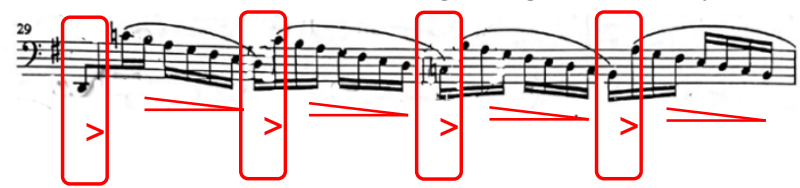

Notasi 37. Dinamika pada Motif yang Membentuk Tangga Nada

(Verlag, 1950: 5)

Pada birama 31 - 36 dimulailah motif yang berbeda. Disini terdapat bagian codetta menuju ending. Pada birama 31 dilakukan penekanan pada nada F\# pertama kali karena menunjukkan dimulainya motif baru tersebut atau menunjukkan dimulainya codetta. Secara otomatis nada F\# dimainkan lebih forte dari nada lainnya. Not-not setelah nada F\# dimainkan lebih lembut dengan dinamika yang stabil. Baru pada birama33 saat jari 
mulai menggunakan posisi empat mulai ada aksen-aksen lagi di beberapa nada yang penting.

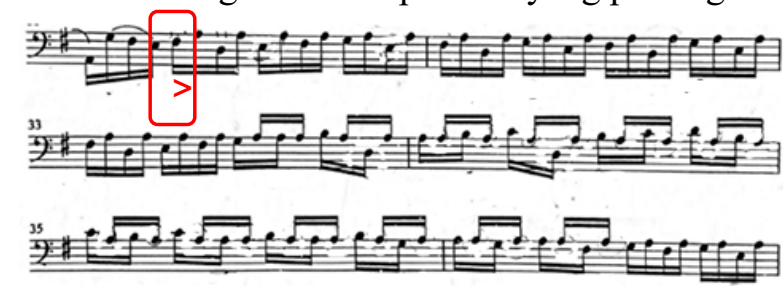

Notasi 38. Dinamika pada Pedal Points dan Garis Melodi

(Verlag, 1950: 5)

Kemudian pada birama 37 masih terdapat motif yang sama teteapi mulai ada crescendo hingga birama 38. Crescendo ini didukung dengan nadanada kromatik yang semakin meningkat dan mengantarkan lagunya menuju klimaks dan ending.

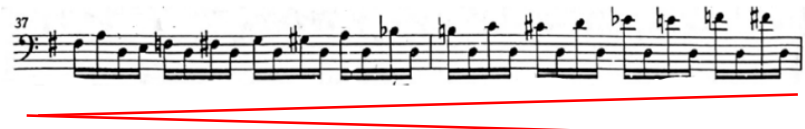

Notasi 39. Dinamika pada Nada Kromatik (Verlag, 1950: 5)

Pada birama 39-41 disinilah klimaks dari lagu ini. Motifnya kembali ke tema awal seperti pada birama1-4 namun dengan susunan yang terbalik dan tanpa adanya pedal not. Pada birama ini not awal dari satu motif dimainkan forte, baik motif pertama maupun kedua. Kemudian diakhiri dengan kadens dalamn $\mathrm{G}$ mayor yang secara otomatis dimainkan secara forte juga karena akhir dari klimaks.

Dalam karya musik Jaman Barok, biasanya ekspresi yang diutarakan dalam karya musik tersebut adalah ekspresi dasar. Ketika sebuah lagu diawali dengan ekspresi senang, maka akan diakhri pula dengan ekspresi senang atau dengan akor mayor. Meskipun tidak berlaku pada semua lagu Jaman Barok, namun hal ini terdapat dalam kebanyakan musik Jaman Barok.

Pada Prelude from Suite No.1 for Violoncello Solo Karya J.S. Bach, lagu ini memiliki nada dasar di G mayor dan dimulai pada G mayor. Artinya lagu ini memiliki ekspresi yang senang dan tenang pada awalnya.

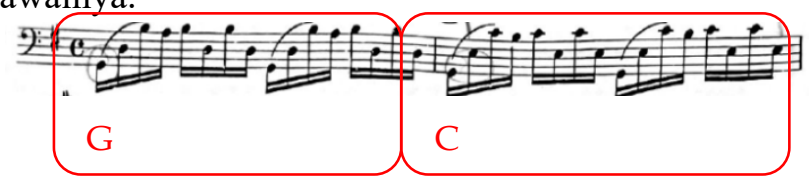

Notasi 40. Akor Mayor pada awal Bagian (Verlag, 1950: 5)
Akor mayor tersebut terus berlanjut hingga birama 4. Mulai dari birama 5 hingga 13 akan ditemui beberapa kor minor seperti $\mathrm{E}$ minor dan A minor. Pada birama-birama tersebut suasananya tetap tenang namun dengan karakter yang lebih gelap yang disebabkan oleh munculnya beberapa akor minor tersebut.

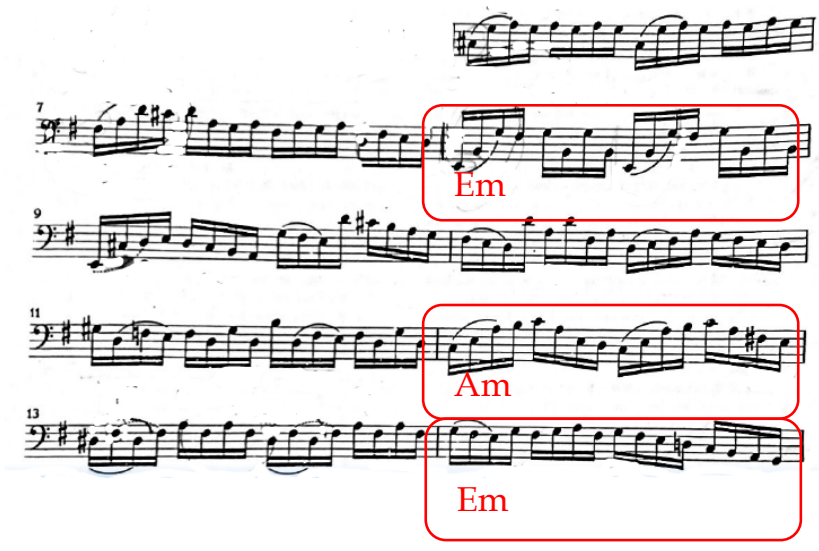

Notasi 41. Akor-akor Minor

(Verlag, 1950: 5)

Pada birama berikutnya adalah birama-birama menuju ending dari bagian I. Dalam bagian ini akorakor dimainkan menjadi tenang dengan karakter yang lebih cerah karena sudah tidak terdapat akorakor minor.

Pada awal bagian II yang terdiri dari rangkaian nada-nada berurutan suasananya lebih mengalir. Dengan munculnya beberapa aksen dari nada-nada berurutan tersebut muncullah seperti lagu tersebut sedang berbicara kepada penikmatnya. Saat tempo semakin naik di bagian codetta, J.S. Bach seperti menunjukkan sebuah kesimpulan dari lagu yang dia tulis ini kemudian diakhiri dengan ending pada akor $\mathrm{G}$ mayor yang dimainkan dengan forte dan bisa diambil kesimpulan bahwa lagu ini berakhir dengan ekspresi yang senang, seperti awal lagu.

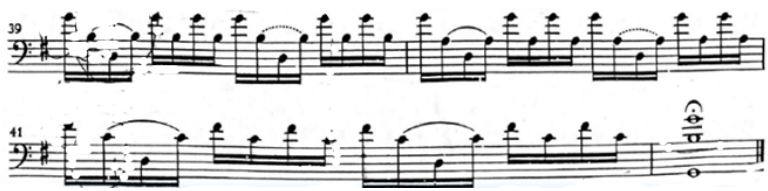

Notasi 42. Coda dengan ekspresi senang (Verlag, 1950: 5)

Hal ini sesuai dengan teori ekspresi dari musik Jaman Barok yang menyatakan bahwa apabila sebuah lagu diawali dengan ekspresi yang senang, maka akan diakhiri dengan ekspresi yang senang pula. Begitu pula sebaliknya. 
Wildany Mafazatin Nailiyah

ANALISIS INTERPRETASI MUSIK JAMAN BAROK PADA PRELUDE FROM SUITE NO.1 FOR VIOLONCELLO SOLO

KARYA J.S. BACH

\section{PENUTUP}

Prelude from Suite No.1 for Violoncello Solo Karya J.S. Bach memiliki bentuk dual yang merupakan ciri khas dari musik jaman barok. Bagian pertama memiliki motif-motif yang membentuk arpegio dan bagian kedua membentuk rangkaian nada yang berurutan. Selain memiliki bentuk dual, karya musik ini tergolong dalam tipe prelude arpeggientyp yang merupakan prelude dengan banyak arpegio-arpegio, terlihat jelas pada bagian pertama. Prelude ini juga tergolong dalam tipe toccatentyp dimana nada-nadanya terdengar seperti improvisasi yang tertulis, terlihat pada bagian kedua. Terbukti dengan beberapa rangkaian nada yang naik dan turun. Pada penginterpretasiannya, Prelude from Suite No.1 for Violoncello Solo Karya J.S. Bach harus dilihat dari motif, frase, mana not yang didetache, mana not yang diberi articulatory silence, dan bagaimana penerapan dinamika yang benar. Apabila beberapa batasan dalam aturan-aturan interpretasi musik jaman Barok tersebut diterapkan maka akan dihasilkan permainan dengan interpretasi musik Jaman Barok. Jadi karya musik yang dimainkan sesuai dengan bagaimana seharusnya karya tersebut diinterpretasikan.

\section{DAFTAR PUSTAKA}

Banoe, P.2003. Kamus Musik. Yogyakarta. Kanisius Donington, R. 1963. The Interpretation of Early Music. London. Faber and Faber

Hermeren, G. 2001. The full voic'd quire: tipe of interpretation of music. In Krausz, M. (eds). The Interpretation of Music. New York: Oxfod University Press.

Karyawanto, H. Y.2018.Bentuk Lagu dan Ambitus Nada Pada Orkestrasi Mars Unesa. Virtuoso (Jurnal Pengkajian Dan Penciptaan Musik), 1(1), 8-14.

Mary, C. 1992. Performing Baroque Music.

Amadeus Press. New York. USA

McNeill, R.J. 1998. Sejarah Musik Jilid 1. Jakarta. PT. BPK GunungMulia

Moleong, L.J. 2001. Metodologi Penelitian

Kualitatif. Bandung: PT Remaja Rosdakarya

Prier, K.E. 1996. Ilmu Bentuk Musik. Yogyakarta.
Pusat Musik Liturgi

Prier, K.E.2007. Sejarah Musik Jilid 2. Yogyakarta. Pusat Musik Liturgi

Prier K.E.2011. Kamus Musik. Yogyakarta. Pusat Musik Liturgi

Stein, Leon. 1979. Structure \& Style: The Study and Analysis of Musical Forms Expanded Edition. United State of America: Summy Birchard.

Sugiyono. 2005. Memahami Penelitian Kualitatif. Bandung: Alfabeta

Sugiyono.2011. Metodologi Penelitian Kuantitatif Kualitatif dan $R \& D$. Bandung: Alfabeta

Syafiq, M. 2003. Ensiklopedia Musik Klasik. Yogyakarta. Adi Cita

Tambajong, J. 1992. Ensiklopedi Musik. Jakarta. PT. Cipta Adi Pustaka

Tambajong. 1998. Ensiklopedi Nasional Indonesia. Jakarta: PT. Cipta Adi Pustaka

Tim Penyusun. 2014. Panduan Penulisan dan Penilaian Skripsi. Surabaya. Unesa

Veilhan, J.C. 1979. The Rules of Musical Interpretation in TheBaroque Era. Paris. Alphonse Leduc 